\title{
NATURAL HISTORY OF LUMBAR CANAL STENOSIS: CLINICAL ASPECTS AND SAGITTAL BALANCE
}

\author{
HISTÓRIA NATURAL DA ESTENOSE DO CANAL LOMBAR: ASPECTOS CLÍNICOS \\ E DO EQUILÍBRIO SAGITAL
}

\section{HISTORIA NATURAL DE LA ESTENOSIS DEL CANAL LUMBAR: ASPECTOS CLÍNICOS Y DEL EQUILIBRIO SAGITAL}

\author{
Vagner Clayton de Paiva, ${ }^{1}$ Marcelo Italo Risso Neto, ${ }^{2}$ Guilherme Rebechi Zuiani, ${ }^{2}$ Ivan Guidolin Veiga, ${ }^{2}$ Wagner Pasoualin, ${ }^{2}$ Marcos Antonio Tebet, ${ }^{2}$ Rodrigo \\ Amaral, ${ }^{3}$ Rubens Girald Jensen, ${ }^{3}$ Luis Marchi, ${ }^{3}$ Luiz Henrique de Mattos Pimenta, ${ }^{3}$ Paulo Tadeu Maia Cavali, ${ }^{2}$ Alberto Cliouet Júnior ${ }^{4}$ \\ 1. Universidade Estadual de Campinas - UNICAMP, Spinal Surgery Course of Study, Campinas, SP, Brazil. \\ 2. Universidade Estadual de Campinas - UNICAMP, Spinal Surgery Group, Campinas, SP, Brazil. \\ 3. Instituto de Patologia da Coluna, São Paulo, SP, Brazil. \\ 4. Universidade Estadual de Campinas - UNICAMP, Department of Orthopedics and Traumatology, Campinas, SP, Brazsil.
}

\begin{abstract}
Objective: To compare the sagittal alignment (SA) parameters in individuals with LCS and surgical indication with a control group and to study the correlations between SA parameters and ODI, VAS and EQ-5D in individuals with LCS and surgical indication. Methods: In this multicenter cross-sectional case-control study, the individuals were allocated as follows. A stenosis group (SG) composed by patients with LCS confirmed by magnetic resonance imaging with surgical indication, treated between July 2010 and August 2016 and a control group (CG), without LCS. All subjects underwent anamnesis, completed the Health-related Quality of Life (HRQLL) and total spine radiographs were taken. Clinical data, HRQoL and radiographic parameters were correlated. Results: Sixty-four individuals formed the SG and 14 the CG. The SG had higher values of mean age, coronal imbalance, sagittal vertical axis (SVA), pelvic tilt (PT), sacrofemoral distance (SFD), overhang (OH), PI-LL mismatch, Oswestry Disability Index (ODI) and Visual Analog Scale (VAS) for pain and smaller thoracic kyphosis (TK), total (TLPL) and regional lumbopelvic lordosis (RLPL) in all vertebrae, sagittal offset (SO) in all evaluated vertebrae and EuroQol-5D (EQ-5D) with $p<0.05$. In the SG, the only significant correlations $(p<0.05)$ were between TK and ODI and EQ-5D; all the other sagittal parameters did not correlated with VAS, ODI or EQ-5D. Conclusion: SG had SA parameters altered in relation to CG. There was a direct correlation between decrease in TK and worsening of ODI and EQ-5D in SG. Level of evidence: III; Case Control Study.
\end{abstract}

Keywords: Spine; Quality of Life; Radiography; Spinal Stenosis; Natural History.

\section{RESUMO}

Objetivo: Comparar parâmetros do AS em indivíduos portadores de EDL com indicação cirúrgica aos de uma população controle; estudar a correlação entre os questionários ODI, VAS e EQ-5D a parâmetros do AS nos portadores de EDL com indicação cirúrgica. Métodos: Estudo transversal multicêntrico tipo caso-controle. Grupo estenose (GE) composto por portadores de EDL, confirmada por Ressonância Nuclear Magnética, com indicação cirúrgica, atendidos entre Julho de 2010 a agosto de 2016. Grupo controle (GC) sem EDL. Todos os indivíduos realizaram anamnese, responderam questionários de qualidade de vida e realizaram radiografias de coluna total. Dados clínicos, questionários e parâmetros radiográficos foram correlacionados. Resultados: 64 indivíduos formaram o GE e 14 o GC. GE apresentou valores maiores de idade média, desequilíbrio coronal, sagital vertical index (SVA), pelvic tilt (PT), sacrofemoral distance (SFD), overhang (OH), missmatch PI - LL, Owestry Disability Index (ODI), Visual Analogic Scale (VAS) e valores menores de cifose torácica, lordose lombopélvica total e regional em todas as vértebras, offset sagital em todas as vértebras avaliadas e EuroQol-5D (EQ-5D), com $p<0,05$. No GE, houve correlações significativas $(p<0,05)$ apenas entre TK e ODI e EQ-5D, sendo que todos os outros parâmetros sagitais não apresentaram correlação significativa com os questionários de qualidade de vida. Conclusão: GE apresentou perda dos parâmetros de AS em relação ao GC. Houve correlação direta entre diminuição da TK e piora do ODI e EQ-5D no GE. Nível de Evidência III; Estudo de Caso Controle.

Descritores: Coluna Vertebral; Qualidade de Vida; Radiografia; Estenose Espinal; História Natural.

\section{RESUMEN}

Objetivo: Comparar los parámetros del alineamiento sagital (AS) en individuos con ECL e indicación quirúrgica con un grupo control y estudiar las correlaciones entre los parámetros de SA y ODI, EVA y EQ-5D en pacientes con ECL e indicación quirúrgica. Métodos: En este estudio multicéntrico de casos y controles, los individuos fueron asignados como sigue. Un grupo estenosis (GE) compuesto por pacientes con ECL confirmada por imágenes de resonancia magnética con indicación quirúrgica, tratados entre julio de 2010 y agosto de 2016 y un grupo control (GC) sin ECL. Todos los individuos se sometieron a una anamnesis, respondieron el cuestionario de Calidad de Vida Relacionada con la Salud (HRQoL) y se tomaran radiografías totales de la columna. Se relacionaron datos clínicos, HRQoL y parámetros radiográficos. Resultados: Sesenta y cuatro individuos formaron el GE y 14 el GC. El GE tenía valores más altos de edad promedio, desequilibrio coronal, eje sagital vertical (ESV), inclinación pélvica (IP), distancia sacrofemoral (DSF), protuberancia (P), falta de emparejamiento IP -LL, Índice

Study conducted at the Hospital das Clínicas da Universidade Estadual de Campinas - UNICAMP, Campinas, SP, Brasil, and the Instituto de Patologia da Coluna, São Paulo, SP, Brazil. Correspondence: Rua Abílio Soares, 509/72, Vila Mariana, São Paulo, SP, Brasil. 04002-005. vagnerdepaiva@yahoo.com.br. 
de Discapacidad de Oswestry (ODI), Escala Visual Analógica (VAS) para el dolor y menos cifosis torácica (CT), lordosis lumbopélvica total $(L L P T)$ y regional (LLPR) en todas las vértebras, offset sagital (OS) en todas las vértebras evaluadas y EuroQol-5D (EQ-5D), con $p<0,05$. En el GE, las únicas correlaciones significativas $(p<0,05)$ fueron entre TC y ODI y EQ-5D; todos los demás parámetros sagitales no se correlacionaron con EVA, ODI O EQ-5D. Conclusión: El GE tuvo parámetros de AS alterados en relación con el GC. Hubo correlación directa entre la disminución de TC y el agravamiento del ODI y EQ-5D en el GE. Nivel de evidencia III; Estudio de Caso Controle.

Descriptores: Columna Vertebral; Calidad de Vida; Radiografía; Estenosis Espinal; Historia Natural.

\section{INTRODUCTION}

Degenerative lumbar stenosis (DLS) is a narrowing of the lumbar spinal canal and/or the vertebral foramens, characterized by low back pain, radicular pain, and/or claudication. It is a common clinical condition, affecting more than 200,000 people in the USA, ${ }^{1}$ being the main reason for indications of spinal surgery in patients above 65 years of age and affecting 1 in every 1000 people per year in this age group. ${ }^{2}$ The increasing prevalence of disease, considered an exacerbation of the degenerative physiological process of aging, is expected as the life expectancy of the population continues to rise. ${ }^{3,4}$

Disc degeneration is often associated with DLS, ${ }^{3}$ usually occurring at the lowest lumbar levels ${ }^{5}$ and causing loss of disc height from dehydration. Consequently, there is an overload on the facet joints, with arthritis and facet joint hypertrophy, thus causing a loss of lumbar lordosis (LL). ${ }^{6}$ There is also a dynamic component, since the canal space decreases with extension and increase with the flexion-distraction of the trunk. ${ }^{7}$ Flexion of the trunk increases the area of the lumbar foramens by $12 \%$ and in extension there is a reduction of $15 \%$ of their sectional area. ${ }^{8}$

There is an association between structural changes of the spine and antalgic position, ${ }^{9}$ which culminates in a posture of anteriorization of the trunk. Compensatory mechanisms, such as an increase in pelvic tilt (PT), are activated in an attempt to reduce the loss of sagittal alignment (SA). ${ }^{10}$

Extensive literature supports the importance of SA and the recognition of its compensatory mechanisms in the treatment of degenerative lumbar spine diseases in cases where surgery is indicated. This becomes even more important when intraoperative sagittal correction with instrumentation and vertebral fusion is necessary.11-14

The objectives of this study were to evaluate whether there were any changes in the SA parameters in DLS patients indicated for surgical treatment as compared to a control population and to study the correlation of the SA parameters with the Visual Analog Scale (VAS), ${ }^{15}$ Oswestry Disability Index (ODI), ${ }^{16}$ and EuroQol - 5 Dimensions (EQ$-5 D)^{17}$ in DLS patients with an indication of surgical treatment.

\section{METHODS}

Study and sample design: This was an original cross-sectional multicentric case-control study.

The Stenosis Group (SG) was comprised of patients with DLS confirmed by Magnetic Resonance Imaging with indication of surgical treatment (refractory symptoms after at least 4 months of the best conservative treatment). The Control Group (CG) included healthy individuals without any diagnosed spinal diseases. Data collection took place during the period from 07/03/2010 to 08/12/2016.

Individuals who refused to participate in the study, those with a history of spinal surgery, previously known disease of the hips and/ or pelvis, and individuals with a prior diagnosis of neuropathy were excluded from the study.

Clinical data such as data of evaluation, age, weight, height, tobacco use, and comorbidities were collected, in addition to VAS, ODI, and EQ-5D scores.

This study was approved by the Institutional Review Board (protocol number 50833515.3.0000.5404) and the data were collected after the study participants had signed the Informed Consent Form.

Digitalized frontal and lateral full spinal radiographs were taken of the study subjects in a standing position with hips and knees in extension. In the frontal radiographs, the subjects let their arms hang down close to the body and in the lateral radiographs the arms were flexed at 45 degrees in relation to the plane of the body. We used $30 \times 90 \mathrm{~cm}$ film and the radiographs were centered on T12 during inhalation, with a distance between the film and the focus of 230 $\mathrm{cm}$. The images were digitalized and the parameters were measured and reviewed by an orthopedist familiar with the indices described, using the Arya PACS Aurora v.1.9.19 program (São Bernardo do Campo, Brazil).

Vertebral and spinopelvic parameters measured are shown in Figure 1 and described in Chart 1

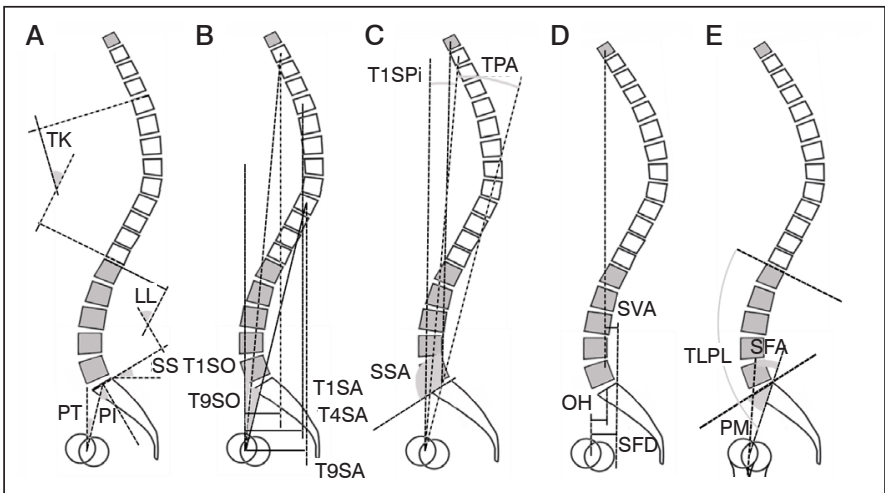

Figure 1. Radiological parameters used in this study.

Chart 1. Radiological parameters used in this study.

\begin{tabular}{|c|c|}
\hline \multirow{5}{*}{ A } & TK (thoracic kyphosis): angle between T4 ptp and T12 dtp \\
\hline & LL (lumbar lordosis): angle between L1 and ptp S1 \\
\hline & SS (sacral slope): angle between S1 ptp and hl \\
\hline & $\begin{array}{l}\text { PT (pelvic tilt): angle between line that joins chr to the midpoint } \\
\text { of the S1 ptp and vl }\end{array}$ \\
\hline & $\begin{array}{l}\text { PI (pelvic incidence): angle between line that touches the chr } \\
\text { and midpoint of the S1 ptp and the line orthogonal to the S1 ptp }\end{array}$ \\
\hline \multirow{2}{*}{ B } & $\begin{array}{l}\text { T1SO and T9SO (sagittal offset in T1 and T9): angle between vl } \\
\text { and the line that connects chr to the respective vc }\end{array}$ \\
\hline & $\begin{array}{l}\text { T1SA, T4SA, and T9SA (sagittal axis): horizontal distance } \\
\text { between chr and the respective vc }\end{array}$ \\
\hline \multirow{3}{*}{$\mathrm{C}$} & $\begin{array}{l}\text { SSA (spinal-sacral angle): angle between line that touches C7 vo } \\
\text { and midpoint of S1 ptp and line tangent to S1 ptp }\end{array}$ \\
\hline & $\begin{array}{c}\text { T1SPi (T1 spinopelvic inclination): angle between vl and line that } \\
\text { touches chr and T1 vc }\end{array}$ \\
\hline & TPA (T1 Pelvic Angle): sum of T1SPi and PT \\
\hline \multirow{4}{*}{$\mathrm{D}$} & SVA (sagittal vertical axis: dh between C7 vc and psIS1 \\
\hline & $\mathrm{OH}$ (overhang): dh between chr and midpoint of S1 ptp \\
\hline & SFD (sacrofemoral distance): dh between chr and splS1 \\
\hline & C7PL/SFD (Barrey Ratio): SVA over SFD \\
\hline \multirow{4}{*}{$\mathrm{E}$} & $\begin{array}{l}\text { TLPL (total lumbopelvic lordosis): angle between T12 dtp and } \\
\text { the pelvic radius }\end{array}$ \\
\hline & $\begin{array}{l}\text { RLPL (regional lumbopelvic lordosis): angle between the ptp of } \\
\text { each lumbar vertebra and the pelvic radius }\end{array}$ \\
\hline & $\begin{array}{l}\text { PM (pelvic morphology): angle between the pelvic radius (line } \\
\text { between chr and spIS1) and S1 ptp }\end{array}$ \\
\hline & $\begin{array}{l}\text { SFA (sacrofemoral angle): between the axis of the femoral } \\
\text { diaphysis and S1 ptp }\end{array}$ \\
\hline
\end{tabular}
Key: ptp - proximal terminal plate, dtp - distal terminal plate, chr - center of hip rotation, $\mathrm{vl}$ - vertica line, hl - horizontal line, vc vertebral centroid, splS1 - superior posterior limit of S1. 


\section{Statistical analysis}

The radiographic measurements and personal characteristics of the CG and SG were described as mean and standard deviation (SD) or median, minimum, and maximum and compared using the Student's T-test or Mann-Whitney test. For the comparison of qualitative measurements, the Fisher's exact test was used. To check the correlation between the radiographic measurements and the questionnaires evaluated for each group, the Spearman correlation was calculated. ${ }^{18}$ The analyses were conducted with the use of IBM-SPSS v. 20.0 software (Chicago, USA) and tabulated using Microsoft-Excel 2003 v. 11.0 software (Redmond, USA). All tests were performed with a level of significance of $5 \%(p<0.05)$

\section{RESULTS}

During the study period, 64 individuals were included in the SG and 14 in the CG. In the SG there were 33 men and 31 women, ranging in age from 34 to 82 years (mean of 60 years). In the CG there were 4 men and 10 women, ranging in age from 25 to 62 years (mean of 49.1 years). Table 1 summarizes the differences in personal characteristics between the two groups and we observed that the only statistically relevant variable was age, lower in the CG.

Table 2 shows that patients in the SG had statistically higher values for coronal imbalance, SVA, PT, SFD, OH, PI-LL mismatch, ODI, and VAS and lower values for TK, TLPL, RLPL in all vertebrae, T1SO, T9SO, and EQ-5D ( $p<0.05)$

Table 3 correlates the clinical and SA parameters with the quality of life questionnaires in the CG. The ODI had no correlation with any of the radiographic parameters evaluated. The VAS presented a correlation with the LLR of $L 4(r=-0.662$ and $p=0.014), L 5(r$ $=-0.624$ and $p=0.023)$, T1 SA $(r=-0.6$ and $p=0.039)$, T9 SA ( $r$ $=-0.607$ and $p=0.036)$, and PI-LL mismatch $(r=-0.599$ and $p$ $=0.024)$. EQ-5D had a positive correlation with the PI-LL mismatch $(r=0.608$ and $p=0.021)$.

Table 4 correlates the radiographic parameters measured to the VAS, ODI, and EQ-5D questionnaires in the SG. It shows that TK presented an inverse correlation with the ODI $(r=-0.273, p=0.038)$ and a direct correlation with the EQ-5D $(r=0.428, p=0.001)$, while there was no relationship observed between parameters such as SVA, SSA, TPA, and PI-LL and the questionnaires in the SG.

It was not possible to visualize the proximal terminal plate of $\mathrm{T} 4$, and therefore not possible to measure TK, in 6 out of the 64 individuals participating in the study. Of the 58 individuals had TK T4-T12 measured, 4 were hypokyphotic, 47 had normal kyphosis, and 7 were hyperkyphotic, considering normal to be between 20 and $40 .{ }^{19}$ Table 5 shows the mean TK, ODI, VAS, and EQ-5D by TK classification group.

\section{DISCUSSION}

Today there is extensive discussion about the real importance of the SA parameters and whether they are able to predict quality of life in the patient with DLS. ${ }^{20-22}$

The data found in our study are in agreement with those reported by Cavali et al. in terms of the loss of SA in the SG as compared to the CG. The same authors also found that the population of DLS patients was older than the randomly selected control group. ${ }^{19}$

Several studies argue that an increase in SVA is associated

Table 1. Study demographic data.

\begin{tabular}{c|c|c|c|c|c}
\hline & \multicolumn{2}{|c|}{ Control } & \multicolumn{2}{c|}{ Stenosis } & \multirow{2}{*}{ P } \\
\cline { 2 - 5 } & mean \pm SD & $\mathbf{N}$ & mean \pm SD & $\mathbf{~ N}$ & \\
\hline Age (years) & $49.1 \pm 11.1$ & 14 & $60 \pm 10.7$ & 64 & 0.001 \\
\hline Weight $(\mathrm{Kg})$ & $75 \pm 16.1$ & 14 & $78.1 \pm 13.5$ & 58 & 0.456 \\
\hline Height $(\mathrm{m})$ & $1.7 \pm 0.1$ & 14 & $1.7 \pm 0.1$ & 58 & 0.282 \\
\hline BMI $\left(\mathrm{Kg} / \mathrm{m}^{2}\right)$ & $25.6 \pm 3.9$ & 14 & $27.5 \pm 3.4$ & 58 & 0.066 \\
\hline Sex $(\mathrm{male})$ & 4 & 14 & 33 & 64 & $0.119^{*}$ \\
\hline Student's T-test; ${ }^{*}$ Chi Square & \multicolumn{4}{|c}{}
\end{tabular}

Table 2. Study radiographic parameters.

\begin{tabular}{|c|c|c|c|c|c|}
\hline & \multicolumn{2}{|l|}{ Control } & \multicolumn{2}{|l|}{ Stenosis } & \multirow[t]{2}{*}{$p$} \\
\hline & $\begin{array}{c}\text { median } \\
(\min ; \max )\end{array}$ & $\mathbf{N}$ & $\begin{array}{c}\text { median } \\
(\min ; \max ) \\
\end{array}$ & $\mathbf{n}$ & \\
\hline $\begin{array}{c}\text { Coronal } \\
\text { imbalance }\end{array}$ & $0(0 ; 15)$ & 14 & $12(0 ; 89)$ & 60 & 0.001 \\
\hline TK & $40.5(25 ; 59)$ & 14 & $39.5(7 ; 67)$ & 62 & 0.629 \\
\hline $\mathrm{LL}$ & $59(48 ; 81)$ & 14 & $49(20 ; 82)$ & 62 & 0.016 \\
\hline SVA & $-10(-35 ; 50)$ & 14 & $28.5(-100 ; 134)$ & 58 & 0.001 \\
\hline PT & $13.5(5 ; 22)$ & 14 & $20(3 ; 42)$ & 62 & 0.006 \\
\hline SS & $41(26 ; 60)$ & 14 & $35.5(13 ; 60)$ & 62 & 0.102 \\
\hline $\mathrm{PI}$ & $52.5(34 ; 82)$ & 14 & $57(29 ; 89)$ & 62 & 0.477 \\
\hline $\begin{array}{c}\text { Cobb coronal } \\
\text { angle }\end{array}$ & $0(0 ; 10)$ & 14 & $1(0 ; 54)$ & 61 & 0.069 \\
\hline TLPL & $92(76 ; 102)$ & 13 & $81(40 ; 104)$ & 61 & 0.001 \\
\hline RLPL L1 & $93(88 ; 103)$ & 13 & $80(50 ; 103)$ & 61 & $<0.001$ \\
\hline RLPL L2 & $92(85 ; 98)$ & 13 & $77(23 ; 108)$ & 61 & $<0.001$ \\
\hline RLPL L3 & $88(74 ; 111)$ & 13 & $71(25 ; 110)$ & 60 & $<0.001$ \\
\hline RLPL L4 & $75(65 ; 118)$ & 13 & $62(28 ; 126)$ & 59 & 0.001 \\
\hline RLPL L5 & $60(50 ; 132)$ & 13 & $51(27 ; 140)$ & 59 & 0.002 \\
\hline $\mathrm{PM}$ & $42(14 ; 150)$ & 13 & $31(6 ; 175)$ & 61 & 0.017 \\
\hline T1 SA & $-41(-86 ; 70)$ & 12 & $-21(-91 ; 105)$ & 51 & 0.294 \\
\hline T4 SA & $-58.5(-115 ; 80)$ & 12 & $-56(-112 ; 75)$ & 56 & 0.748 \\
\hline T9 SA & $-63.5(-117 ; 79)$ & 12 & $-66(-130 ; 54)$ & 58 & 0.726 \\
\hline T1 SO & $7.5(0 ; 10)$ & 12 & $0.5(-16 ; 87)$ & 52 & 0.001 \\
\hline T9 SO & $13(9 ; 21)$ & 12 & $-8(-50 ; 18)$ & 61 & $<0.001$ \\
\hline SFA & $42(10 ; 90)$ & 12 & $50(15 ; 78)$ & 48 & 0.136 \\
\hline SFD & $10(-32 ; 21)$ & 12 & $22(-30 ; 60)$ & 58 & 0.005 \\
\hline $\mathrm{OH}$ & $20(2 ; 47)$ & 13 & $35(-40 ; 73)$ & 58 & 0.005 \\
\hline PI-LL Mismatch & $-8(-25 ; 19)$ & 14 & $8(-19 ; 41)$ & 62 & 0.002 \\
\hline ODI & $6(0 ; 26)$ & 14 & $46(2 ; 68)$ & 60 & $<0.001$ \\
\hline VAS & $0.5(0 ; 6)$ & 14 & $7(0 ; 10)$ & 60 & $<0.001$ \\
\hline EQ-5D & $0.9(0.5 ; 1)$ & 14 & $0.5(0.1 ; 1)$ & 59 & $<0.001$ \\
\hline
\end{tabular}

with a poorer quality of life and an increase in axial pain. ${ }^{23-25}$ In 2013, Schwab concluded that serious clinical disability (ODI > 40) is associated with an increase in SVA, PI-LL mismatch, and PT. ${ }^{26}$ Lafage also concluded that an increase in PT is correlated to a poorer quality of life and that T1SPi is more highly correlated to the quality of life questionnaires than the SVA. ${ }^{27}$

In the literature it is also noted that abnormal TPA values are associated with a worse quality of life in adults with degenerative scoliosis $^{28,29}$ and that an increase in C7PL/SFD is related to a worse quality of life in degenerative lumbar disease. ${ }^{30}$

Nevertheless, most studies that report a correlation between the SA parameters and preoperative quality of life use univariate analysis or multivariate analysis adjusted only for age, ${ }^{23-25,31}$ which creates a strong confusion bias.

Takemoto compared SA parameters with the ODI in 204 cases of adult spinal deformity pre- and postoperatively to deformity correction surgery. In the multivariate analysis, the SA parameters were not significantly correlated with the preoperative ODI. However, he observed that the postoperative improvement in SA resulted in a better ODI. He concluded, therefore, that in surgical cases, reestablishing the SA should be sought with the goal of achieving an improved postoperative ODI, although changes in the SA should not be decisive in a surgical indication. ${ }^{32}$

The lack of a correlation observed between the SA parameters and quality of life in the above-mentioned study is compatible with the data obtained in our study. This raises questions about the reproducibility of the results reported in studies that claim that the SA parameters are predictors of quality of life in individuals with DSL.

Besides the debatable value of using SA parameters to predict quality of life in DSL patients, said parameters are not correlated to non-specific ${ }^{33}$ 
Table 3. Correlation between demographic/radiographic parameters and clinical findings in the CG

\begin{tabular}{|c|c|c|c|c|}
\hline & & ODI & VAS & EQ-5D \\
\hline \multirow{2}{*}{ Age } & $r$ & 0.201 & 0.182 & -0.073 \\
\hline & $p$ & 0.491 & 0.533 & 0.804 \\
\hline \multirow{2}{*}{ BMI } & $r$ & -0.042 & -0.369 & 0.316 \\
\hline & $\mathrm{p}$ & 0.886 & 0.194 & 0.270 \\
\hline \multirow{2}{*}{ Tobacco use } & $r$ & -0.189 & -0.444 & 0.434 \\
\hline & $p$ & 0.517 & 0.112 & 0.121 \\
\hline \multirow{2}{*}{ Coronal imbalance } & $r$ & -0.104 & -0.192 & 0.159 \\
\hline & $\mathrm{p}$ & 0.723 & 0.511 & 0.587 \\
\hline \multirow{2}{*}{ TK } & $r$ & 0.284 & 0.275 & -0.460 \\
\hline & $\mathrm{p}$ & 0.326 & 0.340 & 0.098 \\
\hline \multirow{2}{*}{ LL } & $r$ & 0.264 & 0.485 & -0.470 \\
\hline & $p$ & 0.362 & 0.079 & 0.090 \\
\hline \multirow{2}{*}{ SVA } & $r$ & 0.072 & 0.052 & -0.010 \\
\hline & $\mathrm{p}$ & 0.807 & 0.859 & 0.973 \\
\hline \multirow{2}{*}{ PT } & $r$ & -0.050 & -0.166 & 0.433 \\
\hline & $\mathrm{p}$ & 0.864 & 0.571 & 0.122 \\
\hline \multirow{2}{*}{ SS } & $r$ & 0.049 & 0.007 & -0.104 \\
\hline & $p$ & 0.867 & 0.981 & 0.723 \\
\hline \multirow{2}{*}{$\mathrm{PI}$} & $r$ & 0.094 & 0.007 & 0.027 \\
\hline & $\mathrm{p}$ & 0.749 & 0.981 & 0.928 \\
\hline \multirow{2}{*}{ Cobb coronal angle } & $r$ & -0.155 & 0.198 & 0.089 \\
\hline & $\mathrm{p}$ & 0.597 & 0.497 & 0.762 \\
\hline \multirow{2}{*}{ TLPL } & $r$ & 0.051 & 0.250 & -0.081 \\
\hline & $\mathrm{p}$ & 0.870 & 0.410 & 0.793 \\
\hline \multirow{2}{*}{ RLPL L1 } & $r$ & -0.038 & 0.142 & 0.062 \\
\hline & $\mathrm{p}$ & 0.902 & 0.644 & 0.840 \\
\hline \multirow{2}{*}{ RLPL L2 } & $r$ & -0.221 & -0.430 & 0.287 \\
\hline & $p$ & 0.468 & 0.143 & 0.343 \\
\hline \multirow{2}{*}{ RLPL L3 } & $r$ & -0.071 & -0.312 & 0.233 \\
\hline & $\mathrm{p}$ & 0.817 & 0.299 & 0.444 \\
\hline \multirow{2}{*}{ RLPL L4 } & $r$ & -0.464 & -0.662 & 0.468 \\
\hline & $\mathrm{p}$ & 0.111 & 0.014 & 0.107 \\
\hline \multirow{2}{*}{ RLPL L5 } & $r$ & -0.235 & -0.624 & 0.492 \\
\hline & $p$ & 0.440 & 0.023 & 0.088 \\
\hline \multirow{2}{*}{ PM } & $r$ & -0.204 & -0.407 & 0.451 \\
\hline & $\mathrm{p}$ & 0.503 & 0.168 & 0.122 \\
\hline \multirow{2}{*}{ SA T1 } & $r$ & -0.283 & -0.600 & 0.051 \\
\hline & $\mathrm{p}$ & 0.372 & 0.039 & 0.875 \\
\hline SA T4 & $r$ & -0.188 & -0.495 & -0.021 \\
\hline & $\mathrm{p}$ & 0.559 & 0.102 & 0.948 \\
\hline SA TO & $r$ & -0.261 & -0.607 & 0.098 \\
\hline SA IY & $p$ & 0.413 & 0.036 & 0.761 \\
\hline SO T1 & $r$ & 0.005 & 0.134 & -0.011 \\
\hline זו & $p$ & 0.987 & 0.679 & 0.974 \\
\hline SO To & $r$ & 0.451 & 0.196 & -0.262 \\
\hline 3019 & $p$ & 0.141 & 0.541 & 0.411 \\
\hline SFA & $r$ & -0.280 & -0.227 & 0.461 \\
\hline SI & $\mathrm{p}$ & 0.379 & 0.478 & 0.131 \\
\hline SED & $r$ & -0.040 & -0.110 & 0.293 \\
\hline SFU & $p$ & 0.903 & 0.733 & 0.355 \\
\hline $\mathrm{OH}$ & $r$ & 0.079 & 0.014 & 0.078 \\
\hline Uा1 & $p$ & 0.799 & 0.965 & 0.801 \\
\hline PI-L Mismatch & $r$ & -0.368 & -0.599 & 0.608 \\
\hline PI-LL MVISTIICLI & $\mathrm{p}$ & 0.196 & 0.024 & 0.021 \\
\hline
\end{tabular}

Table 4. Correlation between radiographic parameters and quality of life in the Stenosis Group.

\begin{tabular}{|c|c|c|c|c|}
\hline & & ODI & VAS & EQ-5D \\
\hline \multirow{2}{*}{ Coronal Imbalance } & $r$ & 0.144 & 0.229 & 0.089 \\
\hline & $p$ & 0.285 & 0.086 & 0.510 \\
\hline \multirow{2}{*}{ TK } & $r$ & -0.273 & -0.232 & $-0,290$ \\
\hline & $p$ & 0.038 & 0.079 & 0.001 \\
\hline \multirow{2}{*}{ LL } & $r$ & -0.191 & -0.065 & 0.031 \\
\hline & $p$ & 0.151 & 0.630 & 0.820 \\
\hline \multirow{2}{*}{ SVA } & $\mathrm{r}$ & -0.132 & -0.106 & 0.223 \\
\hline & $p$ & 0.338 & 0.441 & 0.102 \\
\hline \multirow{2}{*}{ PT } & $r$ & -0.021 & 0.149 & 0.075 \\
\hline & $p$ & 0.874 & 0.265 & 0.581 \\
\hline \multirow{2}{*}{ SS } & $r$ & -0.248 & -0.021 & 0.126 \\
\hline & $p$ & 0.060 & 0.876 & 0.349 \\
\hline \multirow{2}{*}{$\mathrm{Pl}$} & $r$ & -0.179 & 0.031 & 0.182 \\
\hline & $\mathrm{p}$ & 0.180 & 0.820 & 0.176 \\
\hline \multirow{2}{*}{ Cobb coronal angle } & $r$ & 0.113 & 0.115 & 0.081 \\
\hline & $p$ & 0.402 & 0.394 & 0.552 \\
\hline \multirow{2}{*}{ TLPL } & $\mathrm{r}$ & -0.157 & -0.185 & 0.058 \\
\hline & $p$ & 0.243 & 0.169 & 0.670 \\
\hline \multirow{2}{*}{ RLPL L1 } & $r$ & -0.149 & -0.209 & 0.038 \\
\hline & $\mathrm{p}$ & 0.269 & 0.119 & 0.780 \\
\hline \multirow{2}{*}{ RLPL L2 } & $r$ & -0.156 & -0.228 & 0.047 \\
\hline & $p$ & 0.247 & 0.088 & 0.730 \\
\hline \multirow{2}{*}{ RLPL L3 } & $r$ & -0.092 & -0.255 & 0.004 \\
\hline & $p$ & 0.500 & 0.058 & 0.980 \\
\hline \multirow{2}{*}{ RLPL L4 } & $r$ & 0.085 & -0.221 & -0.089 \\
\hline & $p$ & 0.537 & 0.105 & 0.521 \\
\hline \multirow{2}{*}{ RLPL L5 } & $\mathrm{r}$ & 0.126 & -0.224 & -0.119 \\
\hline & $p$ & 0.358 & 0.101 & 0.390 \\
\hline \multirow{2}{*}{ PM } & $r$ & 0.180 & -0.122 & -0.226 \\
\hline & $p$ & 0.180 & 0.365 & 0.094 \\
\hline \multirow{2}{*}{ SA T1 } & $r$ & -0.062 & 0.067 & 0.039 \\
\hline & $p$ & 0.675 & 0.653 & 0.793 \\
\hline \multirow{2}{*}{ SA T4 } & $r$ & -0.024 & 0.010 & 0.000 \\
\hline & $p$ & 0.867 & 0.945 & 0.998 \\
\hline \multirow{2}{*}{ SA T9 } & $r$ & -0.060 & 0.055 & -0.047 \\
\hline & $p$ & 0.665 & 0.690 & 0.731 \\
\hline $\mathrm{S} \cap \mathrm{T} 1$ & $r$ & -0.212 & -0.161 & 0.126 \\
\hline 5011 & $p$ & 0.148 & 0.275 & 0.393 \\
\hline SO Ta & $r$ & -0.250 & -0.213 & 0.007 \\
\hline 5019 & $\mathrm{p}$ & 0.061 & 0.112 & 0.961 \\
\hline SEA & $r$ & 0.142 & 0.086 & -0.014 \\
\hline SFA & $p$ & 0.346 & 0.572 & 0.929 \\
\hline SED & $r$ & -0.093 & 0.156 & -0.017 \\
\hline SFD & $p$ & 0.499 & 0.256 & 0.902 \\
\hline $\mathrm{OH}$ & $\mathrm{r}$ & -0.067 & 0.076 & 0.063 \\
\hline UH & $p$ & 0.625 & 0.580 & 0.648 \\
\hline $\mathrm{Pl}-1 / \mathrm{mismatch}$ & $r$ & 0.108 & 0.103 & 0.083 \\
\hline PI - LL mismatch & $p$ & 0.420 & 0.443 & 0.538 \\
\hline SSA & $r$ & -0.099 & 0.047 & 0.067 \\
\hline SSA & $p$ & 0.528 & 0.763 & 0.671 \\
\hline T1 SPi & $r$ & 0.031 & 0.126 & -0.026 \\
\hline IISPI & $p$ & 0.857 & 0.464 & 0.879 \\
\hline TPA & $r$ & -0.219 & 0.005 & 0.161 \\
\hline TPA & $p$ & 0.200 & 0.978 & 0.348 \\
\hline C7PI/SFD & $r$ & -0.018 & -0.069 & 0.123 \\
\hline C/PL/SFD & $p$ & 0.909 & 0.660 & 0.431 \\
\hline
\end{tabular}


Table 5. Mean values of TK, ODI, VAS, and EQ-5D according to the kyphosis groups of the $\mathrm{SG}$.

\begin{tabular}{c|c|c|c|c|c}
\hline & TK & ODI & VAS & EQ-5D & $\mathrm{n}$ \\
\hline Hypokyphosis & 13 & 37 & 7.5 & 0.558 & 4 \\
\hline Normal kyphosis & 37 & 44 & 6.3 & 0.476 & 47 \\
\hline Hyperkpyphosis & 48 & 33 & 5.9 & 0.732 & 7 \\
\hline
\end{tabular}

low back and are not useful as a tool for screening this condition. ${ }^{34}$

We did not find a study that correlated TK and quality of life in DSL. A recent descriptive analytical study evaluated 34 women with osteoporosis and observed that a decrease in TK had an inverse correlation to gait performance and to the SF-36, ${ }^{35}$ results similar to those found in our study.
One limitation of our study was comparing a population of DSL patients with surgical indication to a control group with a lower mean age.

\section{CONCLUSION}

This study showed a significant loss in SA parameter values in patients with DSL indicated for surgery as compared to a control population. It also revealed a direct correlation between a decrease in TK and a worsening of the ODI and EQ-5D quality of life indicators in these patients.

All authors declare no potential conflict of interest related to this article.

CONTRIBUTION OF THE AUTHORS: Each author made significant individual contributions to this manuscript. VCP $(0000-0002-7843-236 \mathrm{X})^{\star}$ reviewed the literature, collected the data, and wrote the paper. MIRN (0000-0003-0990-6901)* reviewed the work and contributed to the intellectual concept. WP $(0000-0002-0464-3455)^{\star}$ analyzed the data and reviewed the article. MAT (0000-0003-0346-3564)* analyzed the data and reviewed the article. IGV $(0000-0001-7221-5447)^{\star}$ analyzed the data and performed the final review. GRZ (0000-0002-4240-9096)* reviewed the statistical data and contributed to the intellectual concept. RA $(0000-0003-3007-0571)^{\star}$ collected data and performed statistical analysis. RJ $(0000-0002-2313-7793)^{\star}$ collected data and performed statistical analysis. LM (0000-0002-3447-0399)* collected data and performed statistical analysis. LHMP (0000-0002-5702-5431)* collected data and performed statistical analysis. PTMC $(0000-0001-5226-505 X)^{\star}$ contributed to the intellectual concept and reviewed the research entire project. ACJ (0000-0002-9893-5204)* reviewed the entire project. *ORCID (Open Researcher and Contributor ID).

\section{REFERENCES}

1. Lurie J, Tomkins-Lane C. Management of lumbar spinal stenosis. BMJ. 2016;352:h6234.

2. Joaquim AF, Sansur CA, Hamilton DK, Shaffrey $\mathrm{Cl}$. Degenerative lumbar stenosis. Arq Neuro-Psiquiatr. 2009;67(2b):553-8.

3. Zylbersztejn S, Spinelli LF, Rodrigues NR, Werlang PM, Kisaki Y, Rios AR et al. Degenerative stenosis of the lumbar spine. Rev Bras Ortop. 2012:47(3):286-91.

4. Aebi M. The aging spine. Berlim: Springer; 2003.

5. Zingg PO. Lumbar spinal stenosis. In: Boss N, Aebi M, editors. Disorders of the spine. Berlin: Springer-Verlag Heidelberg; 2008. p. 513-33

6. Ciric I, Mikhael MA, Tarkington JA. Vick NA. The lateral recess syndrome: a variant of the spinal stenosis. J Neurosurg. 1980;53(4):433-43.

7. Schonstrom N, Lindahl S, Willen J, Hansson T. Dynamic changes in the dimensions of the lumbar spinal canal: an experimental study in vitro. J Orthop Res. 1989;7(1):115-21.

8. Inufusa A, An HS, Lim TH, Hasegawa T, Haughton VM, Nowicki BH. Anatomic changes of the spinal canal and intervertebral foramen associated with flexion-extension movement. Spine (Phila Pa 1976). 1996:21(21):2412-20.

9. Ames CP, Smith JS, Scheer JK, Bess S, Bederman SS, Deviren V, et al. Impact of spinopelvic alignment on decision making in deformity surgery in adults. J Neurosurg Spine. 2012:16(6):547-64.

10. Suzuki H, Endo K, Kobayashi H, Tanaka H, Yamamoto K. Total sagittal spinal alignment in patients with lumbar canal stenosis accompanied by intermittent claudication. Spine (Phila Pa 1976). 2010:35(9):344-6.

11. Lim JK, Kim SM. Comparison of Sagittal Spinopelvic Alignment between Lumbar Degenerative Spondylolisthesis and Degenerative Spinal Stenosis. J Korean Neurosurg Soc. 2014;55(6):331-6.

12. Buckland AJ, Vira S, Oren JH, Lafage R, Harris BY, Spiegel MA, et al. When is compensation for lumbar spinal stenosis a clinical sagittal plane deformity? Spine J. 2016;16(8):971-81.

13. Drummond Filho ML, Risso Neto MI, Lehoczki MA Cavali PT, Veiga IG, Zuiani GR, et al. Avaliação dos parâmetros espinopelvicos pelo posicionamento intra-operatório na artrodese de coluna lombossacra. Coluna/Columna. 2013;12(3):228-31.

14. Barrey C. Roussouly P. Le Huec JC. D’Acunzi G. Perrin G. Compensatory mechanisms contributing to keep the sagittal balance of the spine. Eur Spine J. 2013;22(Suppl 6):S834-41.

15. Joyce CR, Zutshi DW, Hrubes V, Mason RM. Comparison of fixed interval and visual analogue scales for rating chronic pain. Eur J Clin Pharmacol. 1975;8(6):415-20.

16. Fairbank JC, Couper J, Davies JB, O'Brien JP. The Oswestry low back pain disability questionnaire. Physiotherapy. 1980;66(8):271-3.

17. Solberg TK, Olsen JA, Ingebrigtsen T, Hofoss D, Nygaard OP. Health-related quality of life assessment by the EuroQol-5D can provide cost-utility data in the field of lowback surgery. Eur Spine J. 2005;14(10):1000-7

18. Kirkwood BR, Sterne JA. Essential medical statistics. Massachusetts: Blackwell Science; 2006

19. Cavali PT, Pasqualini W, Risso MI, Zuiani GR, Miranda JB. Correlation between symptoms and sagittal alignment parameters in patients with lumbar canal stenosis: A case-control study. Coluna/Columna. 2012;11(4):302-9.

20. Boulay C, Tardieu C, Hecquet J, Benaim C, Mouilleseaux B, Marty C, et al. Sagittal alignment of spine and pelvis regulated by pelvic incidence: standard values and prediction of lordosis. Eur Spine J. 2006;15(4):415-22.
21. Suzuki H, Endo K, Mizuochi J, Kobayashi H, Tanaka H, Yamamoto K. Clasped position for measurement of sagittal spinal alignment. Eur Spine J. 2010;19(5):782-6.

22. Decker S, Müller CW, Omar M, Krettek C, Schwab F, Trobisch PD. Sagittal Balance of the Spine - Clinical Importance and Radiographic Assessment. Z Orthop Unfall. 2016;154(2):128-33.

23. Glassman SD, Berven S, Bridwell K, Horton W, Dimar JR. Correlation of radiographic parameters and clinical symptoms in adult scoliosis. Spine (Phila Pa 1976). 2005;30(6):682-8

24. Glassman SD, Bridwell K, Dimar JR, Horton W, Berven S, Schwab F. The im pact of positive sagittal balance in adult spinal deformity. Spine (Phila Pa 1976). 2005;30(18):2024-9

25. Mac-Thiong JM, Transfeldt EE, Mehbod AA, Perra JH, Denis F, Garvey TA, et al. Can c7 plumbline and gravity line predict health related quality of life in adult scoliosis? Spine (Phila Pa 1976). 2009;34(15):519-27

26. Schwab FJ, Blondel B, Bess S, Hostin R, Shaffrey Cl, Smith JS, et al. Radiographicalspinopelvic parameters and disability in the setting of adult spinal deformity: a prospective multicenter analysis. Spine (Phila Pa 1976). 2013;38(13):803-12

27. Lafage V, Schwab F, Patel A, Hawkinson N, Farcy JP. Pelvic Tilt and Truncal Inclination. Two Key Radiographic Parameters in the Setting of Adults With Spinal Deformity. Spine (Phila Pa 1976). 2009;34(17):E599-606

28. Protopsaltis TS, Schwab FJ, Bronsard N, Smith JS, Klineberg E, Mundis G, et al. The $\mathrm{t} 1$ pelvic angle, a novel radiographic measure of global sagittal deformity, accounts for both spinal inclination and pelvic tilt and correlates with health-related quality of life. J Bone Joint Surg Am. 2014;96(19):1631-40.

29. Yang M, Yang C, Xu Z, Chen Z, Wei X, Zhao J, et al. Role of T1 Pelvic Angle in Assessing Sagittal Balance in Outpatients With Unspecific Low Back Pain. Medicine (Baltimore). 2016;95(9):e2964.

30. Barrey C, Jund J, Noseda O, Roussouly P. Sagittal balance of the pelvis-spine complex and lumbar degenerative diseases. A comparative study about 85 cases. Eur Spine J. 2007;16(9):1459-67

31. Fu KM, Bess S, Shaffrey $\mathrm{Cl}$, Smith JS, Lafage V Schwab F, et al. Patients with adult spinal deformity treated operatively report greater baseline pain and disability than patients treated nonoperatively; however, deformities differ between age groups. Spine (Phila Pa 1976). 2014;39(17):1401-7.

32. Takemoto $M$, Boissière $L$, Vital JM, Pellisé $F$, Perez-Grueso FJ, Kleinstück $F$, et al. Are sagittal spinopelvic radiographic parameters significantly associated with quality of life of adult spinal deformity patients? Multivariate linear regression analyses for pre-operative and short-term post-operative healthrelated quality of life. Eur Spine J. 2017;26(8):2176-86.

33. Gautier J, Morilon P. Marcelli C. Does spinal morphology influence the occurrence of low back pain? A retrospective clinical, anthropometric, and radiological study. Rev Rhum Engl Ed. 1999;66(1):29-34

34. Araújo F, Lucas R, Alegrete N, Azevedo A, Barros H. Sagittal standing posture, back pain, and quality of life among adults from the general population: a sex-specific association. Spine (Phila Pa 1976). 2014;39(13):E782-94.

35. Sangtarash F, Manshadi FD, Sadeghi A. The relationship of thoracic kyphosis to gait performance and quality of life in women with osteoporosis. Osteoporos Int. 2015;26(8):2203-8. 